\title{
RADA EUROPY WOBEC TERRORYZMU - ELEMENTY STRATEGII PRZECIWDZIAŁANIA
}

\section{Wprowadzenie}

Terroryzm jako zjawisko i problem natury międzynarodowej zaistniał po raz pierwszy w efekcie zamachu dokonanego w 1934 r. w Marsylii, w którym zginęli król Jugosławii Aleksander i francuski minister spraw zagranicznych Jean Louis Barthou, co oczywiście nie oznacza, że akty o charakterze terrorystycznym nie miały miejsca już wcześniej. Jednak dopiero to wydarzenie wywołało pierwszą wspólną reakcję państw europejskich w postaci przyjęcia w 1937 r. w Genewie pod auspicjami Ligi Narodów Konwencji o zwalczaniu i zapobieganiu terroryzmowi ${ }^{1}$, która między innymi przewidywała ustanowienie Międzynarodowego Trybunału Karnego dla karania terrorystów, a przede wszystkim formułowała pierwszą uzgodnioną między państwami definicję terroryzmu. Konwencja po raz pierwszy przewidziała stosowanie ekstradycji do sprawców ataków terrorystycznych².

W myśl Konwencji za akt terroru uznano przestępstwa skierowane przeciwko innemu państwu niż to, na którego terytorium są popełnione i zmierzające do wywołania stanu zastraszenia w umysłach określonych osób, grup lub całego społeczeństwa. Akt ów mógł przybrać postać każdego umyślnego czynu powodującego śmieré, uszkodzenie ciała albo utratę wolności osobistości oficjalnych, bądź też mógł być dokonany z zamiarem zagrożenia ich życia, umyślnego niszczenia lub uszkadzania własności publicznej, a także wyrobu, nabywania, posiadania lub dostarczania amunicji i materiałów wybuchowych do popełniania takich przestępstw. Szerokie zakreślenie ram pojęcia aktu terroru stanowiło czynnik opóźniający ratyfi-

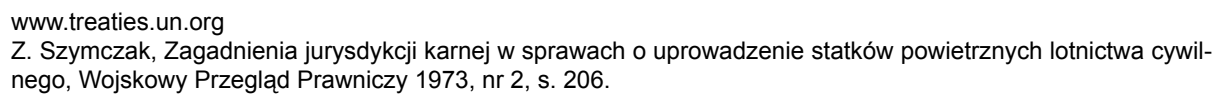


kację Konwencji, a wybuch II wojny światowej przekreślił możliwości jej wejścia w życie ${ }^{3}$.

W ciągu ostatnich osiemdziesięciu lat ewolucji zjawiska terroryzmu nastąpiła nie tylko jego eskalacja ilościowa w postaci zwiększenia liczby ataków terrorystycznych oraz liczby zaangażowanych w działalność terrorystyczną organizacji i osób, ale przede wszystkim wystąpiły przemiany jakościowe, które uczyniły terroryzm jednym z najbardziej palących problemów na przełomie wieków, głównie jako oręża ludzi walczących o swoje polityczne czy religijne racje. Terroryzm uznaje się współcześnie za akt gwałtu o znaczeniu międzynarodowym. ${ }^{4}$ Terroryzm występuje także w postaci nacechowanej kryminalnie (terroryzm kryminalny) jako środek wiodący do celu, którym jest maksymalizacja zysku ze zorganizowanej przestępczości ${ }^{5}$. Aktualny pozostał problem braku międzynarodowego konsensusu co do jednolitego rozumienia istoty zjawiska, a tym samym zaprogramowania wspólnej strategii zwalczania, choć należy pozytywnie podkreślić coraz szerszy zasięg współpracy i kształtujący się, przynajmniej na forum USA - państwa europejskie nowy, sprzyjający zwalczaniu terroryzmu ,klimat polityczny”. Klimat ów umożliwił wypracowanie nowych instrumentów prawa międzynarodowego, które zasiliły katalog dotychczas istniejących środków prawnych i pozytywnie wpłynęły na skuteczność zwalczania terroryzmu ${ }^{6}$.

Podstawową przeszkodę na drodze ku przyjęciu konwencji uniwersalnej, od momentu narodzenia się tej idei, stanowiły problemy z określeniem samej istoty pojęcia terroryzmu, której rozumienie przez poszczególne państwa uwarunkowane jest względami natury politycznej. Problemy pojawiają się głównie wokół dwóch zasadniczych kwestii. Pierwszą jest wyłączenie z zakresu definicji walki narodowowyzwoleńczej, czego domagają się państwa muzułmańskie, drugą zaś żądanie przez państwa zachodnie wyłączenia tzw. terroryzmu państwowego ${ }^{7}$. Nie ulega zatem wątpliwości, iż zarówno prace nad powszechnie akceptowanym aktem prawa międzynarodowego, którego przedmiotem regulacji miałaby być problematyka terroryzmu, jak i całe internacjonalne podejście do tego zjawiska, zdeterminowane są aktualną sytuacją polityczną na arenie międzynarodowej. W związku z powyższym

Z. Galicki, Terroryzm, prawo i polityka, Rzeczpospolita 2002, nr 212, s. C3.

K. Liedel, P. Piasecka, Współpraca międzynarodowa w zwalczaniu terroryzmu, Warszawa 2004, s. 10.

Terroryzm przybierać może zróżnicowane postaci: m.in. cyberterroryzm, terroryzm w sektach czy narkoterroryzm.

Podstawowe akty prawa międzynarodowego w kwestii zwalczania terroryzmu to: Europejska konwencja o zwalczaniu terroryzmu Strasburg 1977 r., Konwencja o zwalczaniu bezprawnych czynów skierowanych przeciwko bezpieczeństwu lotnictwa cywilnego Montreal 1971 r., Konwencja o zwalczaniu bezprawnego zawładnięcia statkami powietrznymi, Haga 1970 r., Konwencja w sprawie przeciwdziałania bezprawnym czynom przeciwko bezpieczeństwu żeglugi morskiej Rzym 1988 r., Protokół w sprawie przeciwdziałania bezprawnym czynom przeciwko bezpieczeństwu stałych platform umieszczonych na szelfie kontynentalnym Rzym 1988 r., Konwencja w sprawie zwalczania finansowania terroryzmu, Nowy Jork $1999 \mathrm{r}$.

Według koncepcji terroryzmu państwowego, popieranej przez państwa arabskie, islamskie oraz część państw Trzeciego Świata, akt terrorystyczny może zostać popełniony również przez osoby reprezentujące państwo (członków sił zbrojnych państwa). 
trudno oczekiwać, aby w najbliższej przyszłości przyjęto uniwersalną konwencję o charakterze supraregionalnym, która przyczyniłaby się do zwiększenia efektywności w zwalczaniu terroryzmu ${ }^{8}$.

Wymaga podkreślenia, iż do dnia dzisiejszego nie udało się wypracować powszechnie akceptowanej definicji terroryzmu. W piśmiennictwie wskazuje się na istnienie ponad stu definicji ${ }^{9}$. Nawiązując do współczesnej istoty zjawiska, na plan pierwszy wysuwają się trzy, występujące w niemalże wszystkich definicjach terroryzmu, cechy:

- użycie przemocy,

- cel zastraszenia,

- szczególna motywacja jako podłoże działania (zwykle o charakterze politycznym lub religijnym).

Oczywistym jest, iż zjawisko terroryzmu w postaci, jaką przybrało w XXI wie$\mathrm{ku}$, ma charakter wysoce złożony i niejednorodny, występuje w wielu formach organizacyjnych i posługuje się zróżnicowanymi metodami, dążąc do różnorodnych celów. Podłożem tego fenomenu jest splot czynników społeczno-ekonomicznych, historyczno-politycznych, socjologicznych i psychologicznych ${ }^{10}$.

Z uwagi na reprezentowaną ideologię możemy wyodrębnić w terrorystycznej działalności następujące nurty: islamistyczny (Al Kaida, Hamas, Dżihad, Hezbollah), separatystyczno-narodowościowy (IRA, ETA, organizacje korsykańskie), anarchistyczno-lewacki (Frakcja Czerwonej Armii, Czerwone Brygady), lewackiego ekstremizmu (Japońska Czerwona Armia Tupamaros w Urugwaju, ERP w Argentynie), neofaszystowski (Nowy Ład we Włoszech), narodowowyzwoleńczy (OWP), ekologiczny (Animal Liberation Front w Wielkiej Brytanii) ${ }^{11}$.

Fenomen międzynarodowego terroryzmu politycznego bez wątpienia jest jedną z najgroźniejszych ,ppatologii” naszej cywilizacji w XXI wieku. Aktualnie można stwierdzić, że podejmowane wcześniej na arenie politycznej próby deprecjonowa-

Brak powszechnie obowiązującej definicji zjawiska nie oznacza, że próby w kierunku jej uzgodnienia nie są podejmowane. Intensywne prace prowadzone sa na forum reaktywowanego w 1996 r. komitetu ad hoc do spraw terroryzmu oraz Komitetu Prawnego ONZ. Pomijając wyżej zasygnalizowane problemy wyłączeń, treść konwencji została już opracowana. W myśl projektu „popełnia przestępstwo w rozumieniu niniejszej konwencji każda osoba, jeżeli ta osoba bezprawnie i umyślnie powoduje śmierć lub poważne uszkodzenia ciała człowieka albo poważne uszkodzenia własności publicznej lub prywatnej, włączając miejsca publicznego użytku, urządzenia państwowe lub rządowe, system transportu publicznego, urządzenia infrastruktury lub środowiska; albo jeżeli ta osoba powoduje uszkodzenia własności, miejsc, urządzeń, systemów wymienionych wyżej, pociagające za sobą lub mogące pociagać za sobą z dużym prawdopodobieństwem wielkie straty ekonomiczne, gdy celem tego postępowania jest $z$ jego natury lub kontekstu zastraszenie ludności albo zmuszenie rządu lub organizacji międzynarodowej do dokonania lub powstrzymania się od dokonania pewnego aktu".

9 K. Indecki, Prawo karne wobec terroryzmu i aktu terrorystycznego, Łódź 1998, s. 22.

10 S. Pikulski, Prawne środki zwalczania terroryzmu, Olsztyn 2000, s. 29 i n.

11 Ibidem, s. 19-20. 
nia skali zagrożenia poprzez wskazywanie na fakt, że ani liczba ofiar, ani też liczba zamachów terrorystycznych nie wzrosły znacząco, należy jednoznacznie uznać za chybione, ponieważ kryterium oceny efektów działalności terrorystycznej stanowi wywołane poczucie strachu, przerażenia i podjęte pod ich wpływem decyzje polityczne (vide np. wycofanie się Hiszpanii z Iraku po zamachach z 11 marca 2004 r.). Eskalacja poczucia zagrożenia wynika nie tyle z liczby czy skali zamachów, co z ich spektakularności, której znaczącym elementem jest symbolika czyniąca zamachy jeszcze bardziej ,,atrakcyjnymi” medialnie. Nowoczesne technologie przepływu informacji, tak jak w przypadku świata zorganizowanej przestępczości, tak i przez terrorystów są świadomie i profesjonalnie wykorzystywane. W przypadku organizacji terrorystycznych przekaz medialny służyć ma spotęgowaniu wrażenia zamachu. Informacyjna funkcja mediów stanowi więc miecz obosieczny, który z jednej strony uświadamia zagrożenie, z drugiej zaś je upowszechnia. To właśnie relacja przeprowadzona na żywo przez CNN i symbolika zamachów na World Trade Center, Pentagon i Waszyngton wywarły największe wrażenie, ponieważ zostały zaatakowane na oczach całego świata symbole najpotężniejszego państwa - „wroga islamu”.

\section{Terroryzm w dokumentach Rady Europy}

Problem terroryzmu był przedmiotem zainteresowania wielu organizacji międzynarodowych, co zaowocowało szeregiem regulacji na przestrzeni ostatnich dziesięcioleci. Terroryzmem zajmowały się i nadal zajmują: Organizacja Narodów Zjednoczonych, Rada Europy czy Unia Europejska. Warto zaznaczyć, że jest on także przedmiotem regulacji ustawodawstw wewnątrzkrajowych. W niniejszym opracowaniu zaprezentowano wybrane elementy strategii przeciwdziałania zjawisku terroryzmu wypracowywanej na forum Rady Europy. Należy zauważyć, że aktywność tej organizacji skupiona jest wokół działań na rzecz promocji i ochrony praw człowieka, zaś sama Rada nie jest organizacją nastawioną głównie na przeciwdziałanie terroryzmowi (podejmowanie działań prewencyjnych czy zwalczających terroryzm).

Biorąc jednak pod uwagę, że Rada stanowi płaszczyznę współpracy na szczeblu politycznym, także w obszarze newralgicznych współczesnych patologii, do których niewątpliwie należy terroryzm, niebagatelną rolę w przeciwdziałaniu takim zjawiskom odgrywają wypracowane przez Radę dokumenty. W obszarze problematyki terroryzmu można wskazać na następujące podstawowe akty:

- Europejską Konwencję o zwalczaniu terroryzmu ${ }^{12}$, 
- Protokół zmieniający Europejską Konwencję o zwalczaniu terroryzmu ${ }^{13}$,

- Konwencję o zapobieganiu terroryzmowi ${ }^{14}$,

- Konwencję o praniu, ujawnianiu, zajmowaniu i konfiskacie dochodów pochodzących z przestępstwa oraz o finansowaniu terroryzmu ${ }^{15}$.

Już sama intytulacja kolejnych Konwencji przyjmowanych na przestrzeni dziesięcioleci wskazuje na ewolucję postrzegania fenomenu terroryzmu. O ile w $1977 \mathrm{r}$. Rada Europy kładła główny nacisk na zwalczanie terroryzmu, o tyle już prawie trzydzieści lat później przyjęła dokumenty, w których pojawia się sformułowanie: „zapobieganie terroryzmowi”. Taki stan rzeczy jasno wskazuje na próbę tworzenia pewnej strategii eliminowania nie tylko przejawów działalności terrorystycznej, lecz także niwelowania przyczyn leżących u podstaw kształtowania się zjawiska terroryzmu. Jest to zatem wyraz złożonego podejścia prawodawcy międzynarodowego - podejścia etiologiczno-symptomatologicznego.

W latach siedemdziesiątych ubiegłego stulecia dominowało przeświadczenie o konieczności zwalczania konkretnych organizacji terrorystycznych; ideą przewodnią była zatem walka z przejawami aktywności terrorystycznej. Dramatyczne wydarzenia, które miały miejsce na początku XXI wieku, zmodyfikowały sposób postrzegania zagrożenia terroryzmem, czego efektem stało się bardziej dalekowzroczne podejście do problematyki ze zwróceniem szczególnej uwagi na podłoże zjawiska. Już nie tylko zwalczanie, ale szeroko rozumiane przeciwdziałanie zyskały rolę pierwszoplanową, co znalazło odzwierciedlenie w intytulacjach kolejnych aktów prawnych dotyczących tej problematyki. Wydaje się oczywistym, iż przeciwdziałanie, zawierając w sobie pojęcie zwalczania, wykracza jednak daleko poza nie, obejmując równocześnie zachowania pozostające na przedpolu działań terrorystycznych, warunkujących istnienie i rozwój zjawiska. Mowa tu chociażby o finansowaniu terroryzmu.

Pierwszym dokumentem Rady Europy, datowanym jeszcze na ubiegłe stulecie, jest Europejska Konwencja o zwalczaniu terroryzmu, sporządzona w dniu 27 stycznia 1977 r. w Strasburgu. ${ }^{16}$ Już w preambule tego aktu wskazano na nasilające się przypadki terroryzmu oraz potrzebę podjęcia skutecznych działań w celu zapewnienia, by sprawcy aktów terrorystycznych nie uniknęli ścigania i kary. Uznano, że szczególnie skutecznym narzędziem wiodącym do ukarania sprawców jest instytucja ekstradycji. Niewątpliwie w tle wypracowanej Konwencji pozostawały anarchistyczno-terrorystyczne czyny z użyciem przemocy, w tym zamordowanie 11-tu

Polska ratyfikowała protokół 10 listopada 2004 r. Dz.U. Nr 172, poz. 1803.

Dz.U. 2008 r., Nr 161, poz. 998.

Dz.U. 2008 r., Nr 165, poz. 1028.

Weszła w życie 4 sierpnia 1978 r., natomiast Polska ratyfikowała Konwencję w dniu 30 stycznia 1996 r. z mocą obowiązującą od 1 maja $1996 \mathrm{r}$. 
izraelskich sportowców przez arabskich terrorystów w czasie igrzysk olimpijskich w Monachium w 1972 r. ${ }^{17}$

Konwencja jest wielostronną umową ekstradycyjną, której sygnatariusze zobowiązali się do nieuznawania aktów terrorystycznych jako przestępstw politycznych, co wcześniej mogłoby stanowić przeszkodę ekstradycyjną. Już pierwotnie przedmiotowy zakres obowiązywania Konwencji był dość szeroki, a jego dodatkowego rozszerzenia dokonano na mocy Protokołu zmieniającego.

W art. 1 Konwencji wymieniono pięć kategorii czynów, których nie należy uznawać za przestępstwa polityczne i których popełnienie uzasadnia ekstradycję. Są to:

- przestępstwa wymienione w Konwencji o zwalczaniu bezprawnego zawładnięcia statkami powietrznymi ${ }^{18}$,

- przestępstwa wymienione w Konwencji o zwalczaniu bezprawnych czynów skierowanych przeciwko bezpieczeństwu lotnictwa cywilnego ${ }^{19}$,

- poważne przestępstwa polegające na zamachu na życie, integralność fizyczną lub wolność osób korzystających z ochrony międzynarodowej, w tym przedstawicieli dyplomatycznych,

- przestępstwa polegające na uprowadzeniu, wzięciu zakładników albo na poważnym bezprawnym zatrzymaniu,

- przestępstwa polegające na użyciu bomby, granatu, rakiety, automatycznej broni palnej albo bomby w formie listu lub paczki, jeżeli ich użycie zagraża osobom oraz usiłowanie popełnienia któregokolwiek z określonych powyżej przestępstw albo współudział lub pomocnictwo osobie, która popełnia takie przestępstwo lub usiłuje je popełnić. Konwencja rozszerza zatem postępowanie w przedmiocie ekstradycji także na niektóre formy stadialne i zjawiskowe przestępstwa.

$\mathrm{Z}$ art. 3 Konwencji wynika, iż jej postanowienia mają pierwszeństwo w stosunku do umów i porozumień ekstradycyjnych między państwami-stronami tej konwencji, jak również w stosunku do postanowień Europejskiej konwencji o ekstradycji. $^{20}$ Jest to rozwiązanie wskazujące na szczególną pozycję Konwencji w systemie umów ekstradycyjnych, która jest uprzywilejowanym aktem prawa międzynarodowego, wypierającym inne postanowienia w razie kolizji.

\footnotetext{
17 A. Gruszczak, Historia współpracy w dziedzinie wymiaru sprawiedliwości i spraw wewnętrznych od Trevi do Tampere, (w:) F. Jasiński, K. Smoter (red.), Obszar wolności, bezpieczeństwa i sprawiedliwości Unii Europejskiej. Geneza, stan i perspektywy rozwoju, Warszawa 2005, s. 10.

18 Konwencja sporządzona w Hadze w dniu 16 grudnia 1970 r., Dz.U. z 1972 r. Nr 25, poz. 181.

19 Konwencja sporządzona w Montrealu w dniu 23 września 1971 r., Dz.U. z 1976 r. Nr 8, poz. 37.

20 Konwencja sporządzona w Paryżu dnia 13 grudnia 1957 r., Dz.U. z 1994 r. Nr 70, poz. 307.
} 
Po ponad dwudziestu latach obowiązywania Konwencja wymagała już zmian, gdyż jej pierwotny tekst uległ nieco dezaktualizacji wobec niewystarczającej skuteczności przewidzianych mechanizmów prawnych w walce z terroryzmem. Przede wszystkim Konwencja nie obejmowała wszystkich czynów, które mogłyby być uznane za terrorystyczne lub za współdziałanie z terroryzmem, stąd jej postanowienia okazały się nieefektywne w walce $\mathrm{z}$ terroryzmem ${ }^{21}$.

Modyfikacje zostały przewidziane w Protokole zmieniającym do Europejskiej konwencji o zwalczaniu terroryzmu ${ }^{22}$, który został otwarty do podpisu w czasie 112 sesji ministerialnej Komitetu Ministrów Rady Europy w dniu 15 maja 2003 r. Główne zmiany dotyczą dopuszczalności ekstradycji. W tym kontekście wydłużono katalog przestępstw, których nie można traktować jako polityczne. Rozszerzenie zakresu przedmiotowego Konwencji nastąpiło poprzez odwołanie się wprost do konwencji antyterrorystycznych przyjętych $\mathrm{w}$ minionych latach $\mathrm{w}$ ramach ONZ. ${ }^{23}$

Jak wskazano powyżej, Konwencja wymieniała w art. 1 pięć rodzajów czynów, które nie mogły być uznawane za polityczne. Protokół zmieniający zwiększa ten katalog o przestępstwa związane z: materiałami jądrowymi, aktami przemocy w międzynarodowych portach lotniczych, bezpieczeństwem żeglugi morskiej i stałych platform na morzach oraz finansowaniem terroryzmu. Dodatkowo postanowieniami konwencji objęto też organizowanie wyliczonych przestępstw i zlecanie ich innym osobom. Konwencje i Protokoły, do których odwołuje się Protokół zmieniający, są następujące:

- Konwencja w sprawie zapobiegania i karania przestępstw przeciwko osobom korzystającym z ochrony międzynarodowej, w tym przeciwko dyplomatom $^{24}$,

- Międzynarodowa Konwencja o walce z przestępstwem wzięcia zakładników ${ }^{25}$,

- Konwencja o ochronie fizycznej materiałów jądrowych ${ }^{26}$,

- Protokół dodatkowy do Konwencji Montrealskiej w sprawie zwalczania bezprawnych aktów przemocy w portach lotniczych służących międzynarodowemu lotnictwu cywilnemu z 1988 r. $^{27}$, chińska (red.), Jednostka i społeczeństwo wobec zagrożeń terroryzmem, Biuletyn Biura Informacji Rady Europy 2002, nr 1, s. 83.

22 Dz.U. z 2004 r. Nr 172, poz. 1803.

23 T. Aleksandrowicz, Konwencja Rady Europy o zapobieganiu terroryzmowi - nowe podejście w walce $z$ terroryzmem? Myśl Ekonomiczna i Prawna 2006, nr 3.

24 Dz.U. z 1983 r. Nr 37, poz. 168.

25 Dz.U. z 2000 r. Nr 106, poz. 1123.

26 Dz.U. z 1989 r. Nr 17, poz. 93.

27 Protokół jest $\mathrm{w}$ trakcie ratyfikacji. 
- Konwencja w sprawie przeciwdziałania bezprawnym czynom przeciwko bezpieczeństwu żeglugi morskiej ${ }^{28}$,

- Protokół o zwalczaniu bezprawnych czynów skierowanych przeciwko bezpieczeństwu stałych platform umieszczonych na szelfie kontynentalnym ${ }^{29}$,

- Międzynarodowa Konwencja w sprawie zwalczania terrorystycznych ataków bombowych ${ }^{30}$,

- Międzynarodowa Konwencja o zwalczaniu finansowania terroryzmu ${ }^{31}$.

Jak słusznie zauważył T. Aleksandrowicz, wśród źródeł prawa międzynarodowego, do których odwołuje się Protokół zmieniający, nie ma Konwencji o znakowaniu plastikowych materiałów wybuchowych, podpisanej w Montrealu w dniu 1 marca $1991 \mathrm{r}^{32}$

Należy także wskazać, że Protokół wprowadził pewne dodatkowe ograniczenia ekstradycji, których pierwotnie nie przewidziano w Konwencji. Państwa mogą odmówić ekstradycji, jeśli wydawana osoba byłaby narażona na poddanie torturom lub groziłaby jej kara śmierci. Takie uregulowanie wypełnia niewątpliwą dotychczasową lukę i koreluje z postanowieniami Konwencji o ekstradycji ${ }^{33}$, która w art. 11 postanawia, że jeżeli przestępstwo, w związku z którym żąda się wydania, jest według ustawodawstwa strony wzywającej zagrożone karą śmierci, a taka kara nie jest przewidziana za nie przez ustawodawstwo strony wezwanej lub nie jest tam zwyczajowo wykonywana, można odmówić wydania, chyba że strona wzywająca zagwarantuje w sposób uznany przez stronę wezwaną za wystarczający, że kara śmierci nie zostanie wykonana.

Kolejnym dokumentem wypracowanym na forum Rady Europy jest Konwencja o zapobieganiu terroryzmowi, którą otwarto do podpisu 16 maja 2005 r. w Warszawie, a weszła w życie 1 czerwca 2007 r. Do tego momentu ratyfikowało ją 19 państw: Albania, Andora, Bośnia i Hercegowina, Bułgaria, Chorwacja, Cypr, Dania, Finlandia, Francja, Łotwa, Mołdawia, Czarnogóra, Polska, Rumunia, Federacja Rosyjska, Serbia, Słowacja, Hiszpania i Ukraina, następnie zaś kolejnych 24 członków Rady Europy. Konwencja jest pierwszą umową międzynarodową na świecie zajmującą się problemem prewencji wobec zjawiska terroryzmu. Posiada ona w stosunku do dotychczasowych instrumentów prawa międzynarodowego komplementarny charakter i stanowi wzmocnienie oraz uzupełnienie istniejącego prawnomiędzynarodowego systemu zwalczania terroryzmu. Jak słusznie zauważa T. Aleksandro-

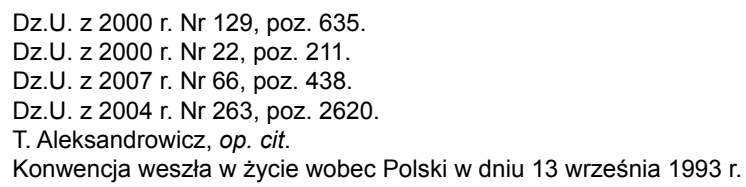


wicz, w Konwencji można odnaleźć pewne ślady koncepcji nowego prawa człowieka, jakim jest prawo do życia bez zagrożenia terroryzmem. ${ }^{34} \mathrm{~W}$ tym kontekście w art. 2 Konwencji wskazano cel tego aktu, jakim jest zapobieganie terroryzmowi i negatywnym skutkom, jakie terroryzm wywiera na pełne korzystanie z praw człowieka, w szczególności prawa do życia.

Z preambuły Konwencji wynika, że jednym z głównych jej celów jest podjęcie skutecznych środków w celu zapobiegania terroryzmowi oraz przeciwstawiania się publicznemu nawoływaniu do popełniania przestępstw o charakterze terrorystycznym, rekrutacji oraz szkoleń na rzecz terroryzmu. W tym też głównie przejawia się prewencyjny charakter Konwencji, która obok instrumentów służących do zapobiegania terroryzmowi zawiera także elementy represji karnej. Istotnym nowym elementem jest zdefiniowanie ,publicznego nawoływania do popełnienia przestępstwa o charakterze terrorystycznym” (art. 5) ${ }^{35}$, ,rekrutacji na rzecz terroryzmu” (art. 6) oraz ,szkolenia na rzecz terroryzmu” (art. 7) $)^{37}$. Każde państwo, będące stroną Konwencji, powinno kryminalizować wymienione wyżej czyny, przyjmując stosowne regulacje w prawie wewnętrznym. jeżeli przestępstwa te zostały popełnione w sposób bezprawny i umyślny.

Warto podkreślić, że werbunek, szkolenie czy publiczne propagowanie idei i haseł terrorystycznych zostały już dostrzeżone także - w na forum Unii Europejskiej jako zjawiska niebezpieczne, będące zalążkiem terroru lub elementem spajającym członków, czy pozwalającym na bardziej intensywny rozwój grup terrorystycznych. W tym kontekście należy zwrócić uwagę na Decyzję ramową Rady z 2008 r., zmieniającą Decyzję ramową z 2002 r. w sprawie zwalczania terroryzmu ${ }^{38}$. W punkcie 11 Preambuły zaznaczono, że należy przewidzieć sankcje dla osób fizycznych, które popełniły umyślnie czyn polegający na publicznym nawoływaniu do popełniania przestępstw terrorystycznych, rekrutacji na potrzeby terroryzmu oraz szkoleniu terrorystycznym, lub dla osób prawnych, które ponoszą odpowiedzialność za ten czyn. Takie formy zachowania powinny być w jednakowym stopniu karalne we wszyst-

34 T. Aleksandrowicz, op. cit.

35 „Publiczne nawoływanie do popełnienia przestępstwa o charakterze terrorystycznym” oznacza rozpowszechnianie lub innego rodzaju udostępnianie przekazu do publicznej wiadomości z intencja podżegania do popełnienia przestępstwa o charakterze terrorystycznym, jeżeli takie zachowanie, bezpośrednio lub pośrednio popierając przestępstwa o charakterze terrorystycznym, stwarza niebezpieczeństwo, że jedno lub więcej takich przestępstw może zostać popełnionych.

36 „Rekrutacja na rzecz terroryzmu” oznacza namawianie innej osoby do popełnienia lub uczestniczenia w popełnieniu przestępstwa o charakterze terrorystycznym lub też do przystapienia do zrzeszenia lub grupy w celu przyczynienia się do popełnienia jednego lub więcej przestępstw o charakterze terrorystycznym przez to zrzeszenie lub grupę.

37 „Szkolenie na rzecz terroryzmu” oznacza dostarczanie wskazówek dotyczących wytwarzania lub wykorzystywania materiałów wybuchowych, broni palnej lub innej broni albo trujących lub niebezpiecznych substancji, bądź też innych szczególnych metod lub technik, w celu popełnienia lub przyczynienia się do popełnienia przestępstwa o charakterze terrorystycznym, ze świadomością, że dostarczone umiejętności mają być w tym celu użyte.

38 Decyzja ramowa Rady 2008/919/WSiSW z dnia 28 listopada 2008 r. zmieniająca decyzję ramową 2002/475/ WSiSW w sprawie zwalczania terroryzmu, Dz.U. UE L z dnia 9 grudnia 2008 r. 
kich państwach członkowskich, niezależnie od tego, czy są popełniane za pośrednictwem Internetu, czy też nie.

Bolesne doświadczenia związane $\mathrm{z}$ atakami terrorystycznymi na początku XXI wieku potwierdziły niewystarczającą skuteczność dotychczas stosowanych środków zwalczania tego zjawiska, konieczność poszukiwania nowych metod i trafność przeniesienia akcentu międzynarodowych działań na zwalczanie finansowania terroryzmu. Kolejnym filarem kształtowanej przez Radę Europy strategii przeciwdziałania zjawisku terroryzmu stała się Konwencja o praniu, ujawnianiu, zajmowaniu i konfiskacie dochodów pochodzących z przestępstwa oraz o finansowaniu terroryzmu sporządzona w Warszawie dnia 16 maja 2005 r. ${ }^{39}$

Novum wśród uregulowań o charakterze międzynarodowym stanowi niejako „podwójne” zadanie tego dokumentu: zapobieganie praniu brudnych pieniędzy oraz zapobieganie wykorzystywaniu takich środków przez terrorystów. Treść konwencji rozszerza pole zakreślone w Konwencji Rady Europy z dnia 8 listopada 1990 r. o praniu, ujawnianiu, zajmowaniu i konfiskacie dochodów pochodzących z przestępstwa, stwarzając podstawy do rozwijania międzynarodowej współpracy w obszarze przeciwdziałania finansowaniu terroryzmu ${ }^{40}$. W preambule znalazło się ponadto odwołanie do Międzynarodowej Konwencji o Zwalczaniu Finansowania Terroryzmu, ze szczególnym uwzględnieniem jej zapisów zobowiązujących państwa-strony do uznania finansowania terroryzmu za przestępstwo kryminalne. Również w kwestii rozumienia pojęcia „finansowanie terroryzmu” zrezygnowano z próby jego autentycznego definiowania, poprzestając na odesłaniu do art. 2 Międzynarodowej Konwencji o Zwalczaniu Finansowania Terroryzmu. Rozwiązanie to podkreśla komplementarność, nie zaś konkurencyjność Konwencji Rady Europy wobec rozwiązań wypracowanych na forum ONZ. Zatem przestępstwo finansowania terroryzmu w świetle obu konwencji popełnia ten, kto jakimikolwiek środkami, bezpośrednio lub pośrednio, bezprawnie i umyślnie, udostępnia lub gromadzi fundusze z zamiarem ich wykorzystania, lub też mając świadomość, że zostaną one wykorzystane, w całości lub w części, do dokonania:

- czynu stanowiącego przestępstwo określonego definicją zawartą w jednym z traktatów wymienionych w aneksie do Międzynarodowej Konwencji o Zwalczaniu Finansowania Terroryzmu;

- czynu mającego spowodować śmierć lub ciężki uszczerbek na zdrowiu osoby cywilnej lub innej osoby nieuczestniczącej aktywnie w działaniach wojennych w sytuacji konfliktu zbrojnego, jeśli celem takiego czynu, wynikającym bądź z jego charakteru, bądź z kontekstu, w jakim jest popełniony, 
jest zastraszenie ludności, albo skłonienie rządu lub organizacji międzynarodowej do dokonania lub do zaniechania określonej czynności ${ }^{41}$.

W preambule wyrażono przekonanie, że zwalczanie ciężkich przestępstw wymaga użycia nowoczesnych i skutecznych metod działania w skali międzynarodowej, a jedną z tych metod jest pozbawianie sprawców przestępstw dochodów z tych przestępstw oraz narzędzi. Dochodem w rozumieniu Konwencji jest każda korzyść ekonomiczna pochodząca lub uzyskana, bezpośrednio lub pośrednio, z przestępstw. Może ona stanowić mienie każdego rodzaju, zarówno materialne, jak i niematerialne, ruchome lub nieruchome oraz dokumenty prawne lub inne stanowiące dowód tytułu do tego mienia lub prawo na tym mieniu. Natomiast narzędzia to każda rzecz użyta lub której zamierza się użyć w jakikolwiek sposób w całości lub w części do popełnienia przestępstwa lub przestępstw.

Rangę problemu finansowania terroryzmu uwypuklono poprzez fakt umieszczenia regulacji w przedmiotowej kwestii już na samym początku Konwencji, w rozdziale II. Zobowiązano w nim strony do przyjęcia środków ustawodawczych i innych, koniecznych dla umożliwienia stosowania postanowień Konwencji w zakresie środków podejmowanych na poziomie krajowym, we współpracy międzynarodowej oraz współpracy pomiędzy JAF (jednostkami analityki finansowej w postaci centralnych, państwowych agencji odpowiedzialnych za otrzymywanie i, w wypadku, kiedy jest to dozwolone, wnioskowanie, analizę i przekazywanie odpowiednim organom ujawnionych informacji finansowych). Strony zobligowane zostały do zapewnienia, iż zdolne są do poszukiwania, śledzenia, identyfikacji, zamrażania, zajmowania i konfiskowania mienia, pochodzącego z legalnego bądź nielegalnego źródła, użytego lub przeznaczonego w jakikolwiek sposób do finansowania terroryzmu lub dochodów z tego przestępstwa oraz do współpracy w tym celu w możliwie najszerszym zakresie.

W piśmiennictwie trafnie dostrzeżono, iż w płaszczyźnie międzynarodowych inicjatyw, między innymi w obszarze działań podejmowanych przez ONZ, ale przede wszystkim w świetle aktywności Rady Europy, występuje pewna dysproporcja w dziedzinie ochrony praw poszczególnych jednostek w kontekście zjawiska terroryzmu. Szeroko podejmowane są problemy związane z ochroną praw człowieka osób zaangażowanych lub podejrzanych o działalność terrorystyczną, natomiast znikomą uwagę poświęca się zagadnieniom praw ofiar terroryzmu. Przekonanie takie wyraził Z. Galicki, który zarzucił międzynarodowym dokumentom ogólnikowość w tej kwestii ${ }^{42}$. Wśród dokumentów Rady Europy problem praw ofiar terroryzmu

41 O przestępstwie finansowania terroryzmu por. W. Filipkowski, System przeciwdziałania finansowania terroryzmu w ujęciu regulacji międzynarodowych, (w:) E.W. Pływaczewski (red.), Aktualne problemy prawa karnego i kryminologii, Białystok 2005, s. 35 i n.

42 Z. Galicki, Zagrożenie terroryzmem a międzynarodowy system ochrony, (w:) J. Szafrański, J. Kosiński (red.), Szczytno 2007, s. 42-44. 
został wzmiankowany w Guidelines on human rights and the Fight against terrorism przyjętych przez Komitet Ministrów 11 lipca 2002 r., w których między innymi mowa jest o odszkodowaniu dla ofiar aktów terrorystycznych. Zagadnieniu temu Rada Europy poświęciła również odrębny dokument w postaci Guidelines on the protection of victims of terrorist acts z $2005 r .{ }^{43} \mathrm{~W}$ pierwszym z wymienionych katalogów guidelines na czele usytuowano obowiązek ochrony każdego przed terroryzmem, spoczywający na państwach. Nie sposób nie zgodzić się ze spostrzeżeniem Z. Galickiego, który zauważa, iż obowiązkowi temu nie odpowiada faktycznie żadne uprawnienie po stronie jednostek w zakresie egzekwowania ochrony od państw ${ }^{44}$. W podobnie ogólny sposób sformułowany został art. 13 Europejskiej Konwencji o Zapobieganiu Terroryzmowi, zatytułowany jako: „Ochrona, odszkodowanie oraz wsparcie dla ofiar terroryzmu".

\section{Rola Komitetu Ekspertów ds. Terroryzmu}

Komitet Ekspertów ds. Terroryzmu (the Committee of Experts on Terrorism, CODEXTER) został powołany do życia w 2003 r. w celu koordynowania działań Rady Europy skierowanych przeciwko terroryzmowi. Zastąpił on Multidyscyplinarną Grupę dla Międzynarodowej Akcji przeciwko Terroryzmowi (the Multidisciplinary Group on International Action against Terrorism, GMT), która zrealizowała postawione przed nią zadanie opracowania Protokołu zmieniającego Europejską Konwencję o Zwalczaniu Terroryzmu z 1977 r. Nowy organ - CODEXTER - ma nie tylko koordynować działania podejmowane przez różne agendy Rady Europy, ale również opracowywać instrumenty prawne służące przeciwdziałaniu zjawisku terroryzmu ${ }^{45}$. W tym zakresie podstawowym zadaniem było przygotowanie kompleksowej konwencji Rady Europy przeciwko terroryzmowi, choć już po powołaniu Komitetu ujawnił się brak zgodności w kwestii zasadności opracowywania takiej konwencji poza forum $\mathrm{ONZ}^{46}$.

Ostatecznie uzgodniono przeniesienie akcentu prac na zapobieganie terroryzmowi, a ich efektem stał się ukończony w 2005 r. projekt, przyjęty następnie w postaci Konwencji o Zapobieganiu Terroryzmowi. Komitet kontynuuje swoją działalność koordynacyjną, ukierunkowując ją na czuwanie nad implementacją przyjętych instrumentów.

H. Machińska (red.), Polska i Rada Europy 1990-2005, Warszawa 2005, s. 211 i n.

Trudności, z którymi CODEXTER zmagał się podczas prac nad projektem, zob. H. Machińska (red.), Polska Rada..., s. 213 i n. 
Rada europy wobec terroryzmu - elementy strategii przeciwdziałania

Obecnie prace CODEXTER koncentrują się w szczególności na:

- przygotowaniu krajowych profili zdolności przeciwdziałania terroryzmowi;

- wymianie informacji i doświadczeń w zakresie kompensacji i systemu ubezpieczeń dla ofiar terroryzmu;

- identyfikacji luk w prawie międzynarodowym i działaniach podejmowanych przeciwko terroryzmowi oraz opracowywaniu propozycji sposobów i środków ich wypełnienia;

- monitoringu podpisywania i ratyfikacji oraz wspierania efektywnego wprowadzania w życie konwencji Rady Europy skierowanych przeciwko terroryzmowi, w szczególności Konwencji Rady Europy o Zapobieganiu Terrory$\mathrm{zmowi}^{47}$.

\section{Zakończenie}

Warunkiem sine qua non skuteczności zwalczania terroryzmu jest istnienie woli państw w kierunku jego wyeliminowania jako narzędzia walki politycznej. Wspieranie organizacji terrorystycznych przez kraje zaliczone przez byłego prezydenta USA G. Busha do tzw. „osi zła” w postaci udzielenia schronienia, a przede wszystkim finansowania ich działalności, jest chyba najtrudniejszą przeszkodą na drodze do likwidacji terroryzmu. Determinantą obniżającą efektywność walki z terroryzmem jest rozwijająca się sieć powiązań pomiędzy organizacjami terrorystycznymi, niekiedy bardzo odległymi od siebie ideologicznie, które współpracują ze sobą m.in. wymieniając informacje czy prowadząc wspólne szkolenia ,żołnierzy”. Kontakty i współpraca rozwijane są również z formacjami o charakterze czysto kryminalnym, głównie ze światem zorganizowanej przestępczości. Ponadto terroryści na coraz większą skalę sięgają po takie źródła finansowania, z których czerpie zyski świat zorganizowanej przestępczości (np. produkcja i handel narkotykami), co również jest znakiem ewolucji zjawiska i zdolności przystosowawczych terrorystów.

Należy oczekiwać, iż korzystne rezultaty przyniesie ratyfikacja przez jak największą liczbę państw Konwencji o praniu, ujawnianiu, zajmowaniu i konfiskacie dochodów pochodzących z przestępstwa oraz o finansowaniu terroryzmu. Nie upłynęło jednak dostatecznie dużo czasu, aby ocenić, jaki rezultat przyniosło opracowanie tego dokumentu.

Zwalczanie terroryzmu musi stanowić przedmiot intensywnie rozwijanej międzynarodowej współpracy, która powinna między innymi polegać na tworzeniu 
i stosowaniu nadążających za rzeczywistością instrumentów prawa międzynarodowego, uderzających w newralgiczne punkty organizacji terrorystycznych (jak np. Międzynarodowa konwencja w sprawie zwalczania finansowania terroryzmu z 1999 r.). Czynnikiem uderzającym pośrednio, lecz z dużą skutecznością, jest gospodarcza i polityczna izolacja państw udzielających terrorystom poparcia, przy jednoczesnym wspieraniu nurtów demokratycznych oraz możliwym łagodzeniu konfliktów narodowościowych.

Pomimo różnorodnych celów i metod działań terrorystycznych, zjawisko powinno zostać jednoznacznie potępione i wykluczone przez społeczność międzynarodową we wszystkich jego przejawach, nawet kiedy stanowi środek odwetu państwowego (ataki Izraela na terrorystów palestyńskich) czy też przejaw narodowowyzwoleńczej walki. Konieczne jest jednoznaczne potwierdzenie w prawie międzynarodowym, iz jedynie siły zbrojne i obiekty o charakterze militarnym mogą być celem ataku i żadnego rodzaju względy nie uprawniają ataku na osoby i obiekty cywilne.

Podsumowując wyżej poczynione rozważania, należy podkreślić, że na forum Rady Europy wypracowano szereg konkretnych rozwiązań w zakresie zarówno zwalczania, jak i zapobiegania terroryzmowi. Niestety, nie udało się uzgodnić jednego projektu konwencji o zwalczaniu terroryzmu, która całościowo traktowałaby tę problematykę. Mamy zatem do czynienia z kilkoma aktami prawnymi, które pozostają względem siebie komplementarne. Przyjęte dokumenty tworzą swoisty prawnomiędzynarodowy system zwalczania terroryzmu, wpisując się w kształtowaną globalnie strategię walki z tym zjawiskiem. Punktem odniesienia dla tego systemu jest przede wszystkim dorobek wypracowany w ramach Organizacji Narodów Zjednoczonych. 


\section{SUMmARY}

The main purpose of this paper is to present selected elements of the Council of Europe strategy to combat the phenomenon of terrorism, in which the major role is played by the Council documents. The dramatic events that took place in the early twenty-first century changed the perception of the threat of terrorism. As a result the approach to the issue a special attention is paid to substrate of the phenomenon.

The Council of Europe developed a series of concrete measures to combat and hence prevent terrorism. Unfortunately, they failed to agree on a convention draft that treats the problem of combat terrorism as a whole. Thus, we have to deal with several acts, which are complementary to each other. Adopted documents form a kind of international legal system against terrorism, as a part of the shaped global strategy to combat this phenomenon. 